\title{
The influence of vocabulary skills and sentence structure with the ability to write a paragraphs description of vocational students
}

\author{
Rahmawati $^{*}$ \\ Universitas Indraprasta PGRI \\ *) Correspondences author: Jalan Raya Tengah No. 80, RT.9/RW.8, Gedong, Pasar Rebo, RT.1/RW.3, Gedong, \\ Kota Jakarta Timur, Daerah Khusus Ibukota Jakarta 13760, Indonesia; e-mail: rhmarisma10@ gmail.com
}

\begin{abstract}
The research aims to determine: (1) the ability to use vocabulary and sentence structure class X SMK Purnama 2 Jakarta-Selatan. (2) the ability to write a paragrafh description and (3) the effect of the ability to use vocabulary and sentence structure to the ability to write a paragrafh description class X SMK Purnama 2 Jakarta-selatan. The research data such as the results of tests of vocabulary and sentence structure in the form of written tests of vocabulary and sentence structure of each of 50 numbers and descriptions essay writing test. The data source is a class $\mathrm{X}$ student of SMK Purnama 2 Jakarta-Selatan. Data were analyzed using multiple linear regression analysis. The results showed that (1) the ability to use the vocabulary class X SMK Purnama 2 Jakarta - Selatan and average value is 38.27 , while the ability to use sentence structure average rating: 37.86 . (2) The ability to write essays description of the class X SMK Purnama 2 Jakarta-Selatan average value is 38.92 and (3) no effect between the ability to use vocabulary and sentence structure to the ability to write a paragrafh description of the class X SMK Purnama 2 Jakarta- Selatan.
\end{abstract}

Keywords: Vocabulary, Sentence structure, Write a paragraph description.

Article History: Received: 12/02/2017; Revised: 26/03/2017; Accepted: 27/04/2017; Published: 05/05/2017

How to Cite (MLA $7^{\text {th)}): ~ R a h m a w a t i . ~ “ T h e ~ i n f l u e n c e ~ o f ~ v o c a b u l a r y ~ s k i l l s ~ a n d ~ s e n t e n c e ~ s t r u c t u r e ~ w i t h ~ t h e ~ a b i l i t y ~ t o ~ w r i t e ~}$ a paragraphs description of vocational students." Hortatori: Jurnal Pendidikan Bahasa dan Sastra Indonesia 1.1 (2017): 6167. Print/Online. Copyrights Holder: Rahmawati. First Publication: Hortatori Jurnal Pendidikan Bahasa dan Sastra Indonesia (2017).

This work is licensed under a Creative Commons Attribution-ShareAlike 4.0 International License.

\section{Pendahuluan}

Pada prinsipnya tujuan pembelajaran bahasa dan sastra Indonesia adalah agar para siswa terampil berbahasa, yaitu terampil mendengarkan, terampil berbicara, terampil membaca dan terampil menulis. Keterampilan menyimak berkenaan dengan bahasa lisan, sedangkan keterampilan membaca dan menulis berkenaan dengan bahasa tulis. Menulis berkaitan erat dengan aktivitas berpikir.

Oleh karena itu, menulis menuntut kemampuan berpikir yang memadai juga menuntut berbagai aspek terkait yang lain, seperti penguasaan materi tulisan pengetahuan bahasa tulis, motivasi yang kuat. Tujuan suatu penulisan itu menyatakan maksud penulis dan pengarang dalam menulis atau mengarang. Berdasarkan penjelasan diatas maka pembicaraan mengenai pelajaran bahasa Indonesia, tidak akan lepas dari kegiatan membaca dan menulis.

Melalui kegiatan membaca siswa akan bertambah kosakatanya dan dengan menulis siswa dapat menuangkan ide atau gagasan yang dimiliki dengan menggunakan kosakata yang telah dikuasai sehingga siswa dapat memahami pembelajaran dengan baik. Kualitas berbahasa seseorang bergantung pada kualitas dan kuantitas kosakata yang dimilikinya. Semakin kaya kosakatanya semakin besar kemungkinan kita terampil berbahasa. 
Adapun standar kompetensi yang berkaitan dengan pembelajaran mengenai kosakata dan menulis deskripsi adalah sebagai berikut: (1) Memahami wacana lisan tentang deskripsi benda benda disekitar dan dongeng (2) Mengungkapkan pikiran, perasaan, dan informasi secara lisan dengan gambar, percakapan sederhana dan dongeng.

Bahasa adalah alat komunikasi yang digunakan manusia dengan sesama anggota masyarakat lain pemakai bahasa. Bahasa berisi gagasan, ide, pikiran, keinginan, atau perasaan yang ada pada diri si pembicara. Agar apa yang dipikirkan, diinginkan, atau dirasakan dapat diterima oleh pembicara atau orang yang diajak bicara, hendaklah bahasa yang digunakan dapat mendukung maksud atau pikiran dan perasaan pembicara dengan jelas. Oleh karena itu, belajar bahasa mengandalkan berpikir, fungsi otak akan bekerja sebagaimana belajar. Bahasa merupakan dasar fundamental berpikir. Bahasa juga dapat memperluas pikiran. Otak mempunyai kapasitas untuk menampung rangsangan-rangsangan yang masuk. Melalui bahasa manusia dapat mengekspresikan pikiran dan perasaannya baik secara lisan maupun tertulis.

Keraf (2009) "Bahasa adalah sistem lambang bunyi yang arbitrer yang digunakan oleh para anggota kelompok sosial untuk bekerjasama, berkomunikasi, dan mengidentifikasikan diri". Pembelajaran bahasa Indonesia merupakan mata pelajaran wajib di lingkungan pendidikan formal. Hal itu, disebabkan oleh kedudukan dan fungsi bahasa Indonesia sebagai bahasa pengantar dalam dunia pendidikan. Pembelajaran bahasa Indonesia bertujuan membantu peserta didik mengembangkan kemampuan mengkomunikasikan berbagai konsep, baik secara lisan maupun secara tertulis. Kemampuan berkomunikasi yang mendasar adalah kemampuan mengungkapkan makna dan pesan termasuk kemampuan menafsirkan, menilai, dan mengekspresikan diri dengan bahasa.

Dalam pendidikan Nasional dirumuskan tujuan pembelajaran bahasa Indonesia, yaitu menjadikan anak didik sebagai manusia yang memiliki kepercayaan akan dasar dan filsafat negara serta kebanggaan terhadap bahasa dan sastra nasionalnya. Selain itu, memberikan anak didik penguasaan atas pemakaian bahasa Indonesia.

Halim menambahkan bahwa prioritas utama pengajaran bahasa Indonesia ditujukan pada sekolah dasar dan menengah karena merupakan penentu pendidikan selanjutnya. Pembelajaran bahasa Indonesia pada sekolah menengah memerlukan perhatian khusus. Dalam pengajaran bahasa, lingkungan kebahasaan yang diciptakan diarahkan untuk meningkatkan kualitas perilaku berbahasa. Oleh karena itu, sekolah dijadikan sebagai salah satu sarana yang sangat strategis dalam memberikan pembinaan dan pengajaran berbahasa kepada siswa.

Pengajaran berbahasa Indonesia di sekolah-sekolah, khususnya di sekolah dasar harus dapat meletakkan dasar kemampuan berbahasa Indonesia yang baik dan benar. Perkembangan kosakata mengandung pengertian lebih dari penambahan kata-kata baru ke dalam perbendaharaan pengalaman siswa. Perkembangan kosakata berarti menempatkan konsep-konsep baru dalam tatanan yang lebih baik atau ke dalam urutan-urutan atau susunan-susunan tambahan. Berdasarkan uraian tersebut dapat dinyatakan bahwa penguasaan kosakata dan struktur kalimat adalah bagian yang sangat penting dalam dunia pendidikan bahasa. Penguasaan kosakata dan struktur kalimat merupakan suatu syarat untuk dapat terampil berbahasa, yaitu terampil menyimak, berbicara, membaca, dan menulis.

Pembelajaran dalam dunia pendidikan menampakkan bahwa media pembelajaran dapat menciptakan suasana belajar yang optimal. Mencermati uraian tersebut dapat dinyatakan bahwa tidak semua siswa di sekolah dapat mencapai hasil belajar yang maksimal. Berbagai usaha yang diterapkan oleh pendidik dalam pembelajaran kosakata dan struktur kalimat, tetapi hasilnya masih belum memuaskan. Dalam hal penguasaan siswa terhadap kosakata dan struktur kalimat yang masih sangat sangat kurang dikarenakan pembelajaran kosakata dan struktur kalimat yang belum memuaskan.

Fenomena yang terjadi dalam konteks pembelajaran kosakata dan struktur kalimat di kelas X SMK PURNAMA 2 Jakarta-Selatan berdasarkan hasil observasi peneliti adalah para murid masih kesulitan dalam berbicara dan menulis yang disebabkan oleh perbendaharaan kosakata dan struktur kalimat yang kurang. Ketika muncul pertanyaan yang berkaitan dengan kosakata tertentu, siswa masih sulit menemukannya. Misalnya, kosakata yang berkaitan dengan lingkungan, maka siswa sulit menciptakan kosakata sebanyak mungkin yang berkaitan dengan lingkungan. Apabila murid ditugasi mengartikan kata tertentu maka siswa tidak memiliki konsep dan pikiran tentang arti kata tersebut. Jika siswa ditugasi mengelompokkan kata-kata berdasarkan kategori (kata sifat, kata benda, kata kerja, kata bilangan, dan kata 
keterangan), maka siswa sulit menyelesaikannya. Kondisi seperti ini sangat berpengaruh terhadap keterampilan menulis siswa khususnya menulis karangan deskripsi.

Masalah yang dialami siswa dalam menulis karangan deskripsi yaitu dari segi penggunaan ejaan yang meliputi penulisan huruf besar, penulisan kata depan, dan penulisan tanda baca yang belum sesuai dengan ejaan yang disempurnakan. Sejalan yang dikemukakan oleh Tarigan (2011) bahwa kualitas keterampilan berbahasa seseorang jelas bergantung kepada kualitas dan kuantitas kosakata yang dimilikinya.Semakin kaya kosakata yang kita miliki maka semakin besar pula kemungkinan kita terampil menulis.

Keberhasilan siswa di sekolah pada setiap mata pelajaran ditentukan oleh perbendaharaan kosakata dan struktur kalimat yang dimilikinya. Banyak orang tidak menyadari bahwa nilai yang tertera pada buku laporan pendidikan siswa itu adalah cermin dari kualitas dan kuantitas kosakata dan struktur kalimat siswa. Baik, sedang, atau kurang nilai yang diperoleh siswa tergantung pada kosakata, struktur kalimat dan keterampilan berbahasa yang dimilikinya. Apabila masalah ini dipahami dengan seksama, maka dapatlah dimengerti betapa pentingnya pengajaran kosakata dan struktur kalimat yang bersistem di sekolah-sekolah terutama di sekolah menengah kejuruan. Kualitas dan kuantitas kosakata dan struktur kalimat seorang siswa turut menentukan keberhasilan siswa itu sendiri.

Kurangnya penguasaan kosakata dan struktur kalimat siswa dipengaruhi oleh penggunaan kosakata dan struktur kalimat dalam kehidupan sehari-hari dan dalam berkomunikasi di lingkungan sekitarnya. Faktor lain yang menyebabkan kurangnya penguasaan kosakata dan struktur kalimat siswa adalah faktor yang bersifat internal maupun yang bersifat eksternal. Salah satu faktor internal adalah latar belakang pemerolehan bahasanya. Kurangnya penguasaan kosakata dan struktur kalimat siswa tersebut dipengaruhi oleh penggunaan bahasa dalam kehidupan sehari-hari. Faktor internal lain adalah pemerolehan bahasa pertamanya. Faktor eksternal adalah sistem pembelajaran yang bersifat konvensional yang menyebabkan lambatnya siswa dalam memperoleh kosakata. Sistem pembelajaran sangat menentukan keberhasilan siswa dalam memahami kosakata tertentu.

Keterampilan menulis merupakan salah satu keterampilan berbahasa yang bersifat produktif keterampilan menulis memiliki sifat yang sama dengan keterampilan berbicara. Keduanya merupakan keterampilan menyampaikan gagasan, perasaan, dan pengalaman kepada orang lain dengan menggunakan bahasa. Dalam bahasa tulis, seorang penulis harus dapat mengungkapkan ide secara jelas, runtut, dan logis. Untuk itu, penulis dihadapkan pada dua masalah, yaitu menyatukan apa yang sebenarnya dimaksudkan dan membuat maknanya jelas bagi pembacanya. Dalam hal ini, dia harus mampu memilih kosakata yang tepat, menyusun dalam kalimat-kalimat yang baik, serta merangkaikannya dalam paragraf-paragraf yang berkesinambungan. Kemampuan menulis meliputi tiga aspek, yaitu aspek isi, aspek retorika, dan aspek kebahasaan. Aspek ini mencakup masalah penulisan dan pengembangan ide pokok, pengembangan kalimat utama menjadi paragraf, dan relevansi isi dengan topik. Aspek retorika membahas pengorganisasian ide termasuk di dalamnya teknik penyampaian. Aspek kebahasaan meliputi tata bahasa, diksi, ejaan, dan tanda baca. Kemampuan menulis pada umumnya bukan merupakan kemampuan bawaan kemampuan ini harus dipelajari dengan baik dan dilatih secara intensif. Untuk menjadi penulis yang terampil seseorang harus menguasai hal-hal berikut ini, yaitu penguasaan terhadap isi yang akan ditulis, penguasaan teknik untuk mengorganisasikan ide dalam tulisan, penguasaan aspek kebahasaan, dan penguasaan unsur mekanik.

Menurut Keraf (2011), tujuan menulis untuk mengungkapkan fakta, perasaan sikap, dan isi pikiran secara jelas dan efektif, termasuk menulis paragraf. Menulis paragraf adalah pengembangan ide pokok atau kalimat utama dengan kalimat penjelas yang merupakan ide-ide penjelasan baik secara deduktif maupun induktif, secara sebab akibat atau akibat sebab pengembangan tersebut dapat dilakukan dengan cara menentukan kata-kata kunci, kemudian kata-kata kunci disusun menjadi kalimat, dan kalimat-kalimat itu disusun menjadi paragraf. Paragraf merupakan suatu piranti untuk berkomunikasi secara tertulis, yakni komunikasi antara penulis dengan pembaca. Seorang penulis menyatakan gagasan atau pikirannya dalam tulisan, sehingga seorang pembaca dapat mengerti ide sedikit demi sedikit hingga keseluruhan kalimat dalam paragraf. Paragraf dapat dipandang sebagai karangan dalam bentuk mini yang mempunyai karakteristik sama dengan karangan lengkap.

Paragraf merupakan karangan yang lengkap, ketiga aspek (aspek isi, retorika, dan aspek kebahasaan) juga terdapat dalam paragraf. Namun demikian, dalam sebuah karangan paragraf tetap merupakan bagian karangan. Digambarkan karena apabila dilihat dari segi isi, isi pokok yang dikemukakan dalam suatu paragraf merupakan perincian dari isi pokok karangan. 
Paragraf yang baik harus memenuhi lima persyaratan, yaitu empat syarat utama dan dan satu syarat bukan faktor utama. Kelima persyaratan itu adalah: (1) adanya kalimat topik, (2) adanya kalimat penunjang, (3) adanya keutuhan pikiran dalam paragraf, (4) adanya keruntutan pikiran untuk memudahkan pembaca memahamipikiran penulis, dan (5) adanya kalimat penyimpul dan ini bukan faktor utama. Kelima persyaratan tersebut harus ada dalam paragraf apabila salah satu syarat tidak ada dalam paragraf berarti paragraf itu tidak lengkap atau tidak baik. Selain itu, paragraf digambarkan baik atau padu apabila hal-hal yang membentuk paragraf terjalin secara erat kepaduan paragraf dapat ditandai dengan berbagai cara, seperti penggunaan kalimat transisi, pengulangan kata kunci, penggunaan kata ganti, dan akan efektif apabila paragraf itu mempunyai kalimat penyimpul.

Pada hakikatnya, yang paling utama disajikan dalam pengajaran bahasa Indonesia adalah kosakata. Mungkin tidak berlebihan kalau dikatakan mempelajari bahasa berarti mempelajari kata-kata dari bahasa itu sendiri. Tanpa penguasaan kosakata yang memadai, seseorang tidak akan pernah memiliki keterampilan berbahasa yang baik, dengan kata lain penguasaan kosakata perlu dimiliki setiap orang untuk menguasai keterampilan berbahasa. Jadi, semakin banyak kosakata yang dikuasai seseorang, maka dapat terampil pula berbahasa dengan baik.

Menurut Chauchard (dalam Mustansyir, 1991) bahwa manusia setiap saat berpikir dengan mempergunakan kosakata dan pengertian. Tanpa kata-kata manusia tidak akan mungkin berpikir, bahkan volume berpikir manusia itu sebanding dengan perbendaharaan kata yang dimilikinya. Kosakata berarti perbendaharaan kata atau kekayaan kata yang dipakai. Sebagai tolok ukur keterampilan berbahasa kosakata merupakan tolok ukur perbendaharaan kata yang dipakai, wawasan kata yang digunakan, serta ketetapan pemakaiannya dalam konteks kalimat.

Keraf (2009) mengatakan bahwa kosakata adalah keseluruhan kata yang berada dalam ingatan seseorang yang segera akan menimbulkan reaksi bila mendengar materi membaca. Selanjutnya, Adwinata (dalam Martono,1990) mengaitkan kosakata sebagai berikut (1) semua kata yang terdapat dalam semua bahasa; (2) kata yang dikuasai oleh seseorang atau kata-kata yang dipakai oleh segolongan orang dalam lingkungan yang sama; (3) daftar sejumlah kata atau frasa dari sebuah bahasa yang disusun secara alfabetis disertai bahasa dan keterangannya.

Berdasarkan pendapat di atas dapat dipahami bahwa kosakata merupakan keseluruhan kata yang dimiliki oleh suatu bahasa, baik yang diucapkan, didengar, ditulis, dan dibaca. Sementara itu, yang dimaksud dengan penguasaan kosakata dalam penelitian ini adalah kemampuan seseorang memperdalam dan menggunakan kekayaan kata ataupun istilah-istilah suatu bahasa, baik dalam menyimak, berbicara, membaca dan menulis konsep-konsep yang ditentukan.

\section{Metode}

Metode yang digunakan dalam penelitian ini adalah metode survei deskriptif dengan teknik korelasional. Variabel Penelitian Penelitian ini memiliki dua variabel bebas dan satu variabel terikat. Variabel bebas terdiri dari kemampuan menggunakan kosakata (X1) dan kemampuan menggunakan struktur kalimat (X2). Variabel terikat yaitu kemampuan menulis paragraf deskripsi (Y). Jenis penelitian ini adalah penelitian korelasi atau penelitian yang ingin mengetahui pengaruh antara dua variabel bebas dengan satu variabel terikat. Oleh karena itu, untuk memperoleh data yang akurat sesuai dengan masalah penelitian ini dirancang secara deskriptif- kuantitatif dengan desain atau model penelitian yang digunakan dalam penelitian ini, yaitu desain penelitian korelasi.

Populasi Populasi penelitian ini adalah seluruh siswa kelas X SMK Purnama 2 yang berjumlah 185 orang yang terdiri atas 5 (lima) kelas. Rincian jumlah tersebut dapat dilihat pada tabel berikut: 
Tabel Populasi Peneitian

\begin{tabular}{ccccc}
\hline \multicolumn{5}{c}{ Jenis Kelamin } \\
\hline No & Kelas & Laki-Laki & Perempuan & Jumlah \\
1 & X & 16 & 21 & 37 \\
2 & XI & 13 & 24 & 37 \\
3 & XII & 17 & 20 & 37 \\
4 & XIII & 17 & 20 & 37 \\
5 & XIV & 18 & 19 & 37 \\
Total & 5 Kelas & 81 & 109 & 185 \\
\hline
\end{tabular}

Menurut Arikunto (2006), populasi adalah keseluruhan subjek penelitian, sedangkan sampel adalah sebagian atau wakil populasi yang diteliti. Tujuan dari penentuan sampel adalah untuk memperoleh keterangan mengenai obyek yang diteliti dengan cara mengamati hanya sebagian dari populasi.

Tujuan lain dari sampel adalah untuk mengetahui sifat-sifat umum dari populasi untuk menarik generalisasi dari hasil penyelidikan, mempermudah penafsiran, peramalan dan pengujian hipotesis. Pada penelitian ini penarikan sampel ditentukan dengan menggunakan teknik random sampling dengan cara undian yang keluar sebagai sampel adalah kelas X.I sebanyak 37 orang.

Teknik Pengumpulan dan Analisis Data Data dalam penelitian ini diperoleh melalui teknik tes, tes adalah serentetan pertanyaan atau latihan serta alat lain yang digunakan untuk mengukur keterampilan, pengetahuan, intelegensi kemampuan atau bakat yang dimiliki oleh individu atau kelompok (Arikunto, 2006). Bentuk tes yang disajikan adalah memberikan tes kosakata dalam bentuk tes pilihan ganda

\section{Hasil dan Diskusi}

\section{Hasil}

Mengacu pada hasil analisis data dapat diketahui bahwa nilai rata-rata kemampuan menulis paragraf deskripsi $(\mathrm{Y})=38,92$ dengan standar deviasi $=3,93$ nilai rata-rata kemampuan menggunakan kosa kata $(\mathrm{X} 1)=38,27$ dengan standar deviasi $=3,79$ dan nilai rata-rata kemampuan menggunakan struktur kalimat $(\mathrm{X} 2)=37,86$ dengan standar deviasi $=3,91$.

Berdasarkan hasil tersebut dapat diketahui bahwa responden (siswa) yang memperoleh skor di bawah rata-rata kemampuan menulis paragraf deskripsi (Y) Sebanyak 6 orang atau 16,22\% dan yang memperoleh nilai diatas rata-rata sebanyak 31 orang $83,78 \%$. Untuk variabel kemampuan menggunakan kosa kata (X1) responden yang memperoleh nilai di bawah sekor rata-rata sebanyak 8 orang atau 21,62\% dan yang memperoleh nilai di atas rata-rata sebanyak 29 orang atau 78,38\% Sedangkan untuk variabel kemampuan menggunakan struktur kata (X2) responden yang memperoleh nilai di atas rata-rata sebanyak 22 orang atau $59,46 \%$.

Secara parsial semua variabel bebas mempunyai pengaruh yang signifikan hal ini bisa dilihat dari nilai thitung maupun Sig, dimana nilai $t$ hitung lebih besar dari t tabel sedangkan nilai Sig masih dibawah Alpha 0, 05.

Variabel kemampuan menggunakan kosakata pengaruhnya signifikan terhadap kemampuan menulis paragraf deskrip ( $\mathrm{t}$ hitung $=3.605>\mathrm{t}$ tabe $!=2,021$ ). Demikian juga nilai $\mathrm{Sig}=0.001<0,05$ dengan koefisien regresi sebesar 0.633. Hal ini menyimpulkan bahwa hipotesis diterima. Demikian juga dengan variabel kemampuan menggunakan struktur kalimat, dengan melihat nilai yang sama seperti di atas dapat disimpulkan bahwa, menggunakan struktur kalimat mempunyai pengaruh signifikan terhadap kemampuan menulis paragraf deskripsi. Hal ini menyimpulkan bahwa hipotesis diterima.

\section{Pembahasan}

Kemampuan menggunakan kosa kata dan sturuktur kalimat Penguasaan kosa kata dan struktur kalimat merupakan dua komponen yang saling berkaitan terus di belajarkan. Dengan pengusaan kosa kata yang baik seseorang akan memiliki wawasan dan pengetahuan kosakata yang luas sehingga diharapkan dapat menyusun kalimat secara lebih baik.

Pada penelitian ini, untuk memperoleh kemampuan menggunakan kosakata dan struktur kalimat siswa kelas X SMK PURNAMA 2 peneliti meminta siswa menuliskan beberapa kosakata kemudian 
menyusun kedalam beberapa kalimat. Dari hasil deskripsi data diketahui bahwa siswa yang memperoleh skor dibawah rata-rata untuk variabel kemampuan menggunakan kosakata (X1) sebanyak 8 orang atau $21,62 \%$ sedangkan siswa yang memperoleh skor diatas rata-rata sebanyak 29 orang atau 78,38\% dan siswa yang memperoleh skor dibawah rata-rata variabel kemampuan menggunakan struktur kalimat (X2) sebanyak 5 orang atau 13,51\% sedangkan siswa yang memperoleh skor diatas rata-rata sebanyak 22 orang atau $59,56 \%$.

Dengan demikian maka dapat disimpulkan bahwa kemampuan penguasaan kosakata merupakan bagian penting dalam menyusun kalimat.Hal tersebut sesuai dengan pendapat Akhadiah (1994) yang menyatakan bahwa kalimat yang baik harus disusun berdasarkan kaidah-kaidah yang berlaku. Kaidah yang berlaku tersebut meliputi (a) unsur-unsur penting yang dimiliki setiap kalimat, (b) cara memilih kata dalam kalimat, dan (c) penerapan aturan aturan tentang ejaan.

Sebagaimana dinayatakan Sugihastuti (2007) bahwa penentuan pilihan kata termasuk sebagai kemapuan penguasaan kosakata dijabarkan sebagai kemahiran penyusunan kalimat efektif dan ketepatan untuk menuliskannya kedalam bentuk paragraf yang baik.

Penguasaan kosakata pada individu dimulai dari pengenalan bahasa ibu melalui proses pembudayaan alami dengan berkembangnya usia, kemudian kosakata diperoleh pada pendidikan formal melalui proses pengajaran dan pembelajaran. Dengan penguasaan kosakata seseorang dapat berkomunikasi dengan orang lain secara lisan maupun tulis tanpa mengalami hambatan.

Berdasarkan pendapat di atas, maka disimpujkan bahwa penguasaan kosakata juga sangat berpengaruh terhadap kemampuan menulis paragraf deskripsi. hal ini dapat dilihat pada kenyataan di lapangan bahwa banyak siswa yang gagal menulis karena penguasaan kosakata yang rendah.

Hasil penelitian itu juga berkorelasi dengan penelitian-penelitian yang dilakukan pada sekolah menengah. Banyak siswa yang kurang berminat dan kurang serius dalam mengikuti pembelajaran menulis. Mereka merasa kesulitan dalam menuangkan ide atau gagasan ke dalam tulisan, baik dalam bentuk puisi, prosa (cerpen), maupun drama.

Kualitas keterampilan berbahasa seseorang sangat dipengaruhi pada kualitas dan kuantitas kosakata yang dimilikinya Tarigan (1994). Semakin kaya kosakata yang dimiliki, semakin terampil pula dalam berbahasa perkembangan kosakata juga merupakan perkembangan konseptual.

Suatu program yang sistematis dalam perkembangan kosakata dipengaruhi oleh usia, jenis kelamin, pendapatan, kemampuan, bawaan, dan status sosial serta faktor-faktor geografis. Pembelajaran kosakata diajarkan dalam konteks wacana, dipadukan dengan kegiatan pembelajaran seperti percakapan, membaca, menulis.

Upaya memperkaya kosakata perlu dilakukan secara terus menerus melalui surat kabar, majalah, pidato-pidato, dan sebagainya. Untuk dapat memperoleh hasil pembelajaran kosakata yang optimal, guru perlu membekali siswa dengan kata-kata yang berkaitan dengan bidang tertentu.

Di masa lampau, pengajaran dan pelajaran kosakata sering diberikan sedikit prioritas dalam program bahasa kedua, tapi akhir-akhir ini sudah ada kepentingan baru dalam hal kosakata dan peranannya dalam pelajaran dan pengajaran. Secara tradisional, pelajaran kosakata sering dibiarkan untuk dipelajari secara mandiri dan hanya menerima sedikit perhatian dalam banyak buku teks dan program bahasa.

Kemampuan menulis paragraf deskripsi Kemampuan menulis paragraf deskripsi siswa kelas $\mathrm{X}$ SMK PURNAMA 2 penelitian ini yaitu rata-rata 38,92 siswa yang memperoleh skor dibawah rata-rata sebanyak 6 orang atau 16,22\% dan siswa yang memperoleh skor diatas rata-rata sebanyak 31 orang atau $83,78 \%$. Kemampuan menulis paragraf deskripsi siswa diperoleh dari hasil tes menulis penguasaan paragraf deskripsi setelah diajar dengan kosakata dan struktur kalimat. Hasil penelitian yang diperoleh yaitu siswa sudah banyak yang mampu menulis paragraf deskripsi dengan baik.

Hasil penelitian tersebut sejalan dengan pendapat Tarigan (1994) yang menyatakan bahwa kegiatan menulis tidak dapat dipisahkan dengan kegiatan menyusun kalimat. Keterampilan menulis merupakan keterampilan yang sangat penting dalam kehidupan tidak hanya penting dalam kehidupan pendidikan tetapi juga sangat penting dalam kehidupan masyarakat. Keterampilan menulis itu sangat penting karena merupakan salah satu keterampilan berbahasa yang harus dimiliki oleh siswa.

Pengaruh antara kemampuan menggunakan kosakata dan struktur kalimat terhadap kemampuan menulis paragraf deskripsi berdasarkan hasil pengujian hipotesis diperoleh nilai $\mathrm{R}=0,9$ dan nilai $\mathrm{F}$ hitung sebesar 314,542 sedangkan nilai $\mathrm{F}$ tabel sebesar 3,28 maka dapat disimpulkan bahwa ada pengaruh antara kemampuan menggunakan kosakata dan struktur kalimat terhadap kemampuan menulis paragraf deskripsi 
siswa kelas X SMK PURNAMA 2. Dengan demikian maka hipotesis alternatif (H1) yang berbunyi "terdapat pengaruh kemampuan menggunakan kosakata dan struktur kalimat terhadap kemampuan menulis paragraf deskripsi siswa kelas X SMK PURNAMA 2" dinyatakan diterima sedangkan hipotesis nihil (H0) yang berbunyi, tidak ada pengaruh kemampuan menggunakan kosakata dan struktur kalimat terhadap kemampuan menulis paragraf deskripsi siswa kelas X SMK PURNAMA 2 dinyatakan ditolak.

Dalam hal ini kemampuan menggunakan kosakata dan struktur kalimat mempunyai pengaruh positif terhadap kemampuan menulis paragraf deskripsi siswa kelas X SMK PURNAMA 2 artinya semakin tinggi kemampuan menulis paragraf deskripsi siswa. Siswa dikatakan siap belajar menulis jika mampu mengingat urutan huruf dan tahu perbedaan, dapat memusatkan ide dan gagasan, serta kembali ke baris berikutnya, mempunyai bahasa tulis yang benar yang berisi kosakata selain pandangan dan percakapan.

\section{Simpulan}

Mengacu pada hasil analisis dan pembahasan terhadap masalah-masalah penelitian dan hipotesis dapat di tarik simpulan sebagai berikut:

Kosakata memegang fungsi dan peranan yang sangat penting dalam keterampilan berbahasa. Kosakata juga dapat menambah ilmu bahasa seseorang sehingga pengetahuan yang dimiliki semakin luas. Dalam penelitian ini kemampuan menggunakan kosakata siswa kelas X SMK PURNAMA 2 nilai rata-ratanya -= 38,27 dengan standar deviasi 3,79.

Kalimat adalah satuan bahasa terkecil dalam wujud lisan atau tulisan yang mengungkapkan pikiran yang utuh. Kemampuan menggunakan srtuktur kalimat siswa kelas X SMK PURNAMA 2 nilai rataratanya= 38,92 dengan standar deviasi $=3,93$.

Terdapat pengaruh secara bersama-sama antara kemampuan menggunakan kosakata dan struktur kalimat terhadap ke mampuan menulis paragraf deskripsi siswa kelas X SMK PURNAMA 2.

Hal ini disebabkan nilai $F$ hitung yang diproleh lebih besar yaitu 314,542 dari pada nilai $F$ tabel yaitu 3,28 atas dasar taraf signifiakasi $5 \%$ dan secara parsial semua variabel bebas mempunyai pengaruh yang signifikan, hal ini disebabkan nilai $\mathrm{T}$ hitung yang diperoleh yaitu 3,605 lebih besar dari nilai T-tabel yaitu 2,021 .

\section{Ucapan Terima Kasih}

Terima kasih kepada semua pihak yang membantu penulis dalam menyelesaikan artikel hasil riset ini sehingga bisa diterbitkan di Jurnal Hortatori.

\section{Daftar Rujukan}

Akhadiah, S. Pembinaan kemampuan menulis. Jakarta: Erlangga, 1994. Print.

Arikunto, S. Prosedur penelitian kualitatif dan kuantitatif. Jakarta: Rineka Cipta, 2006. Print.

Halim, A. Politik bahasa nasional. Jakarta: Pusat Pembinaan dan Pengembangan Bahasa, 2005. Print.

Keraf, G. Tata bahasa Indonesia. Ende: Nusa Indah, 2009. Print.

Keraf, G. Diksi dan gaya bahasa. Jakarta: Gramedia Pustaka Utama, 2011. Print.

Martono. Kosakata bahasa. Jakarta. Depdibud, 1990. Print.

Mustansyir, R. Filsafat bahasa aneka masalah arti dan upaya pemecahannya. Jakarta: Prima Karta, 1991. Print.

Sugihastuti. Tata bahasa baku bahasa Indonesia. Jakarta: Bulan Bintang, 2007. Print.

Tarigan, H.G. Prinsip-prinsip dasar sastra. Bandung: Angkasa Tangan, 1994. Print.

Tarigan, H.G. Pengajaran kosakata. Bandung: Angkasa, 2011. Print. 